\title{
\Genome Medicine
}

\section{Commentary Gene patents and personalized medicine - what lies ahead?}

\author{
Subhashini Chandrasekharan and Robert Cook-Deegan
}

Address: Center for Public Genomics, Duke Institute for Genome Sciences and Policy, Duke University, Durham, NC 27708, USA.

Correspondence: Subhashini Chandrasekharan. Email: shubha.c@duke.edu

\begin{abstract}
Gene patents have generally not impeded biomedical research, but some problems that arise in genetic diagnostics can be attributed to exclusively licensed gene patents. Gene patents for therapeutics have often been litigated but have received surprisingly little public outcry. In stark contrast, genetic diagnostics have been highly controversial but rarely litigated: no case has gone to trial and there is little case law to guide policy. Most recently the Secretary's Advisory Committee for Genetics Health and Society (SACGHS) released a draft report examining how patenting and licensing affect access to clinical genetic testing in the US. The SACGHS reported that patents neither greatly hindered nor facilitated patient access to genetic testing; both the harms and the benefits of patents on genetic diagnostics have been exaggerated. Problems do occur when patents are exclusively licensed to a single provider and no alternative is available. Courts have been changing the thresholds for what can be patented, and how strongly patents can be enforced. Technologies for sequencing, genotyping and gene expression profiling promise to guide clinical decisions in managing common chronic diseases and infectious diseases, and will likely be an integral part of personalized medicine. Developing such genomic tests may require mapping a complex intellectual property landscape and cutting through thickets of patented DNA sequences and related methods. Our preliminary studies have found patent claims that, if strictly enforced, might block the use of multigene tests or full-genome sequence data. Yet new technologies promise to reduce the costs of complete genomic sequencing to prices that are comparable to current genetic tests for a single condition. Courts, companies, and policy makers seem unlikely to allow intellectual property to obstruct such technological advance, but prudent policy will depend on careful analysis and foresight. The SACGHS report signals that the US government is paying attention, and increases the odds that policy will foster socially beneficial uses of genetic testing while preserving intellectual property incentives and mitigating the problems that arise from legal monopolies.
\end{abstract}

\section{Introduction}

In April 2009, the US Patent and Trademark Office (PTO) granted its 50,00oth DNA patent, making at least one claim about DNA or RNA molecules or their uses [1]. A gene patent, as the term is generally used, is a DNA patent that claims rights over nucleic acid sequences encoding proteins, or variants of those sequences. Jensen and
Murray [2] identified 4,270 US patents granted by the end of 2004 that explicitly claimed DNA sequences for 4,382 out of 26,688 (approximately 20\%) human genes catalogued in the RefSeq database. Another study found 16,000 DNA-sequence patents were granted worldwide, with the US PTO granting almost ten times more such patents than either the European or Japanese patent offices from 1980 to 2003 [3].

Gene patents have been of particular interest because of their relevance to biopharmaceuticals and genetic diagnostics. Gene patents underpin production of therapeutic biologic products such as insulin, growth hormone, erythropoietin and other growth factors, or of specific antibodies for biological therapy. Some therapeutic gene patents have been the subject of litigation [4] but there has been relatively little public controversy, perhaps because such patents act much like those on small-molecule drugs.

In contrast, gene patents have repeatedly sparked controversy in the context of genetic testing for Mendelian disorders and mutations predicting risk of common chronic diseases. Media coverage has been predominantly negative. Testing BRCA1 and 2 gene variants to predict inherited risk of breast and ovarian cancer has been particularly controversial, with overwhelmingly negative press coverage, except in Utah, home to Myriad Genetics, the company with exclusive rights to perform diagnostic testing [5]. In May 2009, a consortium of plaintiffs supported by the American Civil Liberties Union filed a lawsuit in federal court in New York against Myriad Genetics and other defendants [6]. Because this lawsuit challenges the validity of claims on isolated nucleotide sequences, the final ruling on the suit could affect the validity of numerous other patents with similarly structured claims for genetic diagnostics as well as therapeutics. Concerns raised about the effects of gene patents on diagnostics include sole provider companies' ability to set a de facto national standard of clinical care, higher costs, lower quality, inhibition of better testing methods, impediments to clinical research, and limitations on medical professionals' education. 


\section{Studies and policy reports on gene patents}

Over the past decade, the UK's Nuffield Council of Bioethics [7], the Australian Law Reform Commission [8], the Organization of Economic Co-operation and Development [9] and the European Society of Human Genetics [10] have prepared policy reports on how patents affect genetic diagnostics. Several case studies suggest that patents and exclusive licensing have reduced the availability of genetic testing for hereditary hemochromatosis, Canavan's disease, and breast cancer [11-17]. In addition, responses to laboratory surveys indicate that patent enforcement has reduced the number of providers for some patented genetic tests [11,17].

The Secretary's Advisory Committee on Genetics Health and Society (SACGHS, US Department of Health and Human Services) is preparing a policy report addressing the effects of patenting and licensing on clinical access to genetic testing in the United States. The SACGHS released a draft report for public comment in March [18], and is likely to release the final report late this year or early in 2010. Our group at Duke University gathered empirical evidence for the SACGHS at the committee's request. We concluded that it is difficult to make evidence-based claims that patents have either substantially helped or hindered clinical and patient access to genetic testing in the US [19].

\section{It is not just what is patented that matters, but how patents are used}

Patenting and licensing of patents relevant to DNA diagnostics interact in complex ways with the US healthcare system. Problems arise when patents covering genetic tests are licensed exclusively to a single test provider and no alternative avenue for testing is available. When the provider does not offer all forms of genetic testing (for example, preimplantation or prenatal testing or testing of paraffin-embedded tissues), or does not have coverage and reimbursement agreements with insurers or health plans, patients cannot turn elsewhere to get a test. Moreover, firms with de facto monopolies on testing for certain conditions have no explicit policies to clarify that they support basic and clinical research, verification of results and 'second opinion' testing, and transparent, independent proficiency testing and quality control. It bears emphasis, however, that case studies of current genetic testing cannot fully predict what issues are likely to arise for future DNA diagnostic technologies.

\section{Genomic diagnostics: past experience may not predict future uses}

Technologies for genotyping, gene expression profiling and full-genome sequencing are advancing with extraordinary rapidity, promising to displace genetic testing methods that have been fairly stable for a decade. New classes of diagnostics can simultaneously detect millions of genetic variations and mutations, and expression-level changes in thousands of genes, or even the entire genome. Genomic diagnostics are beginning to realize the promise of personalized medicine as they increasingly guide choices among treatments, drug doses and preventive interventions for cancer, heart disease, diabetes and infectious diseases.

Navigating the complex intellectual property landscape of DNA patents poses challenges for genomic diagnostics. Multi-gene diagnostic tests may infringe existing DNAsequence or method claims, and difficulty in securing freedom to operate could slow some promising clinical technologies. Concerns include difficulties in aggregating rights to many patent claims and costs of procuring multiple licenses (royalty-stacking), often described as the anticommons effect, and securing rights already exclusively licensed to others by prior agreement (blocking problems). To date, less than $1 \%$ of US 'gene patents' have spawned litigation. This frequency is comparable to patents in general ( 1 to $2 \%$ ). Only five cases have involved genetic diagnostics and all five were settled before going to trial [4]. The rarity of litigation and the complete absence of precedent-setting case law for DNA diagnostics, however, does not imply that patents have no effect. In many cases, it is clear that simply sending letters threatening patent enforcement is sufficient to 'clear the market' of competitors in genetic testing [20]. Litigation is very costly, and many of the relevant economic effects may be lower than the threshold cost of either bringing or fighting a lawsuit. As DNA diagnostics become more valuable and the stakes get big enough to fight about, litigation might become more common. Moreover, the few cases of litigation have involved traditional genetic testing, and not the emerging multi-gene diagnostics. Those developing such new diagnostic technologies are flying in the dark.

\section{Shifting jurisprudence}

Uncertainty about DNA diagnostic patents is compounded by shifts in patent practice and jurisprudence. The US PTO announced higher thresholds for utility and written description of sequence-based patent claims in 1999 and implemented them in early 2001 [21,22]. Recent decisions by the US Court of Appeals for the Federal Circuit and the US Supreme Court have raised the standard for obviousness (KSR International Co. v. Teleflex Inc.) [23], changed criteria for allocating damages for patent infringement proportional to the actual contribution of the patented invention under dispute, and made automatic injunctions more discretionary (eBay Inc. v. MercExchange $L L C$ ) [24]. Two pending cases, Bilski v. Kappos (expected to be decided by the Supreme Court in 2010) [25], and the recent Appeals Court decision in Prometheus v. Mayo [26] promise to be directly relevant to DNA diagnostics, and could change the game. In Europe, there has been even less litigation over diagnostics, and far less patent enforcement than in the US, but commercial genetic testing may become more important there in coming years $[27,28]$. 


\section{The future of patents and diagnostics: continued uncertainty and increasing complexity}

Our preliminary analysis suggests that microarray-based methods of genetic analysis for many genes and gene variants, and a fortiori full-genome sequencing could arguably infringe on some patent claims. However, such claims have never been tested in court, and some appear vulnerable to changing interpretations of what can be patented, so it is difficult to know if they would be held valid if challenged. While much of the attention has focused on patents claiming nucleic acid sequences, claims on specific methods for analyzing or detecting DNA variants are at least as important. In a recent analysis of claims for patents associated with 22 commonly administered genetic tests, van Overwalle and colleagues [29] determined that method claims covering these diagnostics could be harder to 'invent around' than claims on cDNA sequences. A 2006 study [30] showed growth in patents claiming research tools such as methods for gene expression profiling or detecting single nucleotide polymorphisms and even algorithms and software for disease prediction, classification and prognosis. Some patents claim associations between DNA sequences and clinical conditions or medical outcomes and could also prove difficult to work around.

There is no consensus about whether DNA sequence patents hinder or help in the development and availability of genetic diagnostics, and empirical evidence about how these patents may affect commercialization of new genomic diagnostics is scarce. This seemingly innocuous statement is an advance in the public debate, given that the alleged negative consequences and benefits of patents have so often been grossly overstated. The framework for genetic testing is likely to change within the next decade, as the cost of individual whole-genome sequencing drops to levels comparable to current genetic tests for individual conditions. The forthcoming SACGHS report may have a salutary effect on norms and practices in patenting and licensing of technologies relevant to emerging DNA diagnostics, merely by shining a spotlight on them.

\section{Competing interests}

The authors declare that they have no competing financial interests. The authors were part of a team of researchers that gathered empirical evidence for the SACGHS draft report.

\section{Authors' contributions}

$\mathrm{SC}$ and RCD both contributed to the design and writing of this commentary.

\section{Acknowledgements}

The authors gratefully acknowledge the support of the National Human Genome Research Institute and the Department of Energy (CEER Grant P50 HG003391), Duke University, Center of
Excellence for ELSI Research. The authors also thank Arti K Rai for helpful comments and criticism. The authors also acknowledge Christopher Heaney for useful comments and help with editing.

\section{References}

1. Georgetown University: DNA Patent Database [http://dnapatents.georgetown.edu/] (accessed 10 September 2009).

2. Jensen K, Murray F: Intellectual property. Enhanced: intellectual property landscape of the human genome. Science 2005, 310:239-240.

3. Hopkins MM, Mahdi S, Patel P, Thomas SM: DNA patenting: the end of an era? Nat Biotechnol 2007, 25:185-187.

4. Holman CM: Genetics. Trends in human gene patent litigation. Science 2008, 322:198-199.

5. Caulfield T, Bubela T, Murdoch $\mathrm{CJ}$ : Myriad and the mass media: the covering of a gene patent controversy. Genet Med 2007, 9:850-855.

6. Marshall E: Biotechnology. Lawsuit challenges legal basis for patenting human genes. Science 2009, 324:1000-1001.

7. Nuffield Council on Bioethics: The Ethics of Patenting DNA. London: Nuffield Council on Bioethics; 2002 [http://www.nuffieldbioethics.org/fileLibrary/pdf/theethicsofpatentingdna.pdf] (accessed 10 September 2009)

8. Australian Law Reform Commission: Genes and Ingenuity: Gene Patenting and Human Health Report 99. Canberra; 2004 [http://www.austlii.edu.au/au/other/alrc/publications/reports/99/]

9. Organization for Economic Co-operation and Development (OECD): Guidelines for the Licensing of Genetic Inventions. Paris: OECD; 2006 [http://www.oecd.org/dataoecd/39/38/ 36198812.pdf] (accessed 10 September 2009).

10. Aymé S, Matthijs G, Soini S; ESHG Working Party on Patenting and Licensing: Patenting and licensing in genetic testing: recommendations of the European Society of Human Genetics. Eur J Hum Genet 2008, 16(Suppl 1):S10-19.

11. Merz JF, Kriss AG, Leonard DG, Cho MK: Diagnostic testing fails the test. Nature 2002, 415:577-579.

12. Parthasarathy $\mathrm{S}$ : Architectures of genetic medicine: comparing genetic testing for breast cancer in the USA and the UK. Soc Stud Sci 2005, 35:5-40.

13. Parthasarathy S: Building Genetic Medicine: Breast Cancer, Technology, and the Comparative Politics of Health Care. Cambridge MA: MIT Press, 2007.

14. Matthijs G, Hodgson S: The impact of patenting on DNA diagnostic practice. Clin Med 2008, 8:58-60.

15. Sevilla C, Moatti JP, Julian-Reynier C, Eisinger F, StoppaLyonnet D, Bressac-de Paillerets B, Sobol H: Testing for BRCA1 mutations: a cost-effectiveness analysis. Eur $J$ Hum Genet 2002, 10:599-606.

16. Sevilla C, Julian-Reynier C, Eisinger F, Stoppa-Lyonnet D, Bressac-de Paillerets B, Sobol H, Moatti JP: Impact of gene patents on the cost-effective delivery of care: the case of BRCA1 genetic testing. Int J Technol Assess Health Care 2003, 19:287-300.

17. Cho MK, Illangasekare S, Weaver MA, Leonard DG, Merz JF: Effects of patents and licenses on the provision of clinical genetic testing services. J Mol Diagn 2003, 5:3-8.

18. Secretary's Advisory Committee on Genetics Health and Society: Public Consultation Draft Report on Gene Patents and Licensing Practices and Their Impact on Patient Access to Genetic Tests. Bethesda: SACGHS; 2009 [http://oba.od.nih. gov/oba/SACGHS/SACGHS\%20Patents\%20Consultation $\% 20$ Draft\%203\%209\%202009.pdf] (accessed 10 September 2009).

19. Cook-Deegan $R$, Chandrasekharan $S$, Angrist $M$ : The dangers of diagnostic monopolies. Nature 2009, 458:405-406.

20. Secretary's Advisory Committee on Genetics Health and Society Public Consultation Draft Report Appendix 1, Compendium of Case Studies. Bethesda: SACGHS; [http://oba.od.nih. gov/oba/SACGHS/Appendix $\% 201 \% 20$ SACGHS $\% 20$ Patents\%20Consultation\%20Draft\%20Compendium\%20of\%20 Case\%20Studies.pdf] (accessed 10 September 2009). 
21. United States Patent and Trademark Office: Utility examination guidelines. Fed Regist 2001, 66:1092-1099.

22. United States Patent and Trademark Office: Guidelines for written description requirement. Fed Regist 2001, 66:10991111.

23. KSR International Co. v. Teleflex, Inc., 127 S. Ct. 1727 (2007).

24. eBay Inc. v. MercExchange, LLC, 547 U.S. 388 (2006).

25. Bilski v. Kappos, 545 F.3d 943 3d 943 (Fed. Cir. 2008), cert. granted, 556 U.S. 2009 (No. 08-964).

26. Prometheus v. Mayo 2008 WL 878910 (S.D. Cal.). US CAFC 2008-1403, 16 September 2009.

27. Birgit Verbeure, Gert Matthijs, Geertrui Van Overwalle: Analysing DNA patents in relation with diagnostic genetic testing. Eur J Hum Genet 2006,14:26-33.

28. Gaisser S, Hopkins MM, Liddell K, Zika E, Ibarreta D: The phantom menace of gene patents. Nature, 2009, 458:407408.
29. Huys I, Berthels N, Matthijs G, van Overwalle G: Uncertainty in the area of genetic diagnostic testing. Nat Biotechnol 2009 , in press.

30. National Research Council, Committee on Intellectual Property Rights in Genomic and Protein Research and Innovation: Reaping the Benefits of Genomic and Proteomic Research. Washington: National Academies Press; 2005 [http://www.nap.edu/catalog/11487.html] (accessed 10 September 2009).

Published: 28 September 2009

doi:10.1186/gm92

(c) 2009 BioMed Central Ltd 